Т. В. Саварин, Ю. Ю. Яриш, О. В. Денефіль

ДВНЗ “Тернопільський державний медичний університет імені І. Я. Горбачевського

МОЗ України"

\title{
РОЗВИТОК ВИЩОЇ ОСВІТИ ГРЕЦІЇ (НА ПРИКЛАДІ УНІВЕРСИТЕТУ ІМ. АРИСТОТЕЛЯ В М. САЛОНІКАХ)
}

\author{
T. V. Savaryn, Yu. Yu. Yarysh, O. V. Denefil \\ I. Horbachevsky Ternopil State Medical University \\ DEVELOPMENT OF HIGHER EDUCATION IN GREECE (ON THE \\ EXAMPLE OF ARISTOTLE UNIVERSITY OF THESSALONIKI)
}

\begin{abstract}
Мета роботи - розглянути розвиток та здійснити огляд сучасної системи вищої освіти Греції на прикладі Університету ім. Аристотеля в м. Салоніках; визначити тенденції її розвитку.

Основна частина. Вища освіта у Греції існує з перших років становлення нової Грецької держави (1821-1829). Як і колись, вищі навчальні заклади розташовані у двох найбільших містах Греції - в Афінах і Салоніках. Сучасна система вищої освіти Греції децентралізована. Державна освіта є безкоштовна. Вища освіта містить два сектори: університетський та професійнотехнічний. Конституція Греції надає університетам повну автономію та академічну свободу. На сьогодні нараховано 14 вищих навчальних закладів, з них 2 (Афінський і Салонікський університети) є університетами з найбільш розвиненим науководослідним потенціалом. У вищій школі Греції прийнята загальноєвропейська двоетапна загальноосвітня система. Згідно 3 чинною Конституцією Греції, засновувати недержавні вищі освітні заклади в країні заборонено. Університет ім. Аристотеля у м. Салоніках є найбільшим університетом не тільки в Греції, але і на Балканах. У ньому навчається близько 75000 студентів на 11 факультетах. Кожний факультет має у своєму складі декілька шкіл з різними напрямками навчання, загальною кількістю - 40.

Висновки. Дослідивши розвиток вищої освіти Греції, можна стверджувати, що Грецька держава завжди сприяла розвитку системи вищої освіти, яка багато в чому стала сполучною ланкою між державною ідеологією і широкими верствами грецького населення. Усі вищі навчальні заклади Греції створені за принципом найстарішого Афінського університету, тому система вищої освіти Греції потребує заснування принципово нових університетів за організацією роботи, засобами навчання і новими спеціальностями.
\end{abstract}

Ключові слова: вища освіта Греції; Університет ім. Аристотеля в м. Салоніках; медична освіта; розвиток.

The aim of the work - to consider a development and review of the modern system of higher education in Greece on the example of Aristotle University of Thessaloniki; to identify the trends of its development.

The main body. Higher education in Greece has existed since the first years of the development of a new Greek state (1821-1829). As before, higher education institutions are located in the two largest cities of Greece - Athens, and Thessaloniki. The modern system of higher education in Greece is decentralized. Public education is free. Higher education has two sectors: academical and vocational. The Greek Constitution gives universities full autonomy and academic freedom. Today there are fourteen higher educational establishments, of which two (University of Athens and Aristotle University of Thessaloniki) are universities with the most developed research potential. In the high school of Greece adopted a general European two-stage general education system. According to the current Constitution of Greece, the establishment of non-state higher educational institutions in the country is prohibited. Aristotle University of Thessaloniki is the largest university not only in Greece but both the Balkan peninsula. It trains about 75,000 students in 11 faculties. Each faculty has several schools with different directions, with a total of 40 .

Conclusions. We explored the development of higher education in Greece. So we can argue that Greece has always been promoted to the development of a higher education system, which in many ways became a connecting link between the state ideology and Greek population. All higher education institutions in Greece are based on the principle of the oldest University of Athens, so the system of higher education in Greece needs the foundation of fundamentally new universities for the organization of work, learning tools, and new specialties.

Key words: higher education in Greece; Aristotle University of Thessaloniki; medical education; development.

Вступ. Сьогодні українська вища освіта перебуває на етапі євроінтеграційних змін, вона прагне відповідати європейському рівню, а тому потребує постійного вдосконалення. Бажання України приєднатися до єдиного європейського простору

( ) Т. В. Саварин, Ю. Ю. Яриш, О. В. Денефіль вищої освіти та єдиного дослідницького простору зумовлює необхідність розв'язання комплексу завдань, пов'язаних із забезпеченням якісної професійної підготовки фахівців в університетах країни. 3 огляду на це, аналіз та виокремлення найефективніших освітніх зразків, прогресивних 
ідей та передових концепцій, що існують у світовому науковому просторі, та їх адаптація до потреб національної системи освіти є одним із ключових завдань сучасної педагогічної науки.

Наукове дослідження вищезазначених процесів $\epsilon$ актуальним завданням з огляду на перспективи інтеграції України в загальноєвропейський освітній простір. Теорія і практика зарубіжного освітнього процесу стали предметом наукового пошуку провідних українських науковців (Н. Абашкіної, Г. Алєксевич, О. Олексюка, Г. Єгорова, О. Ковязіної, Л. Латун, Б. Мельниченка, Є. Москаленко, О. Овчарук, О. Рибак, Г. Степенко, І. Тараненко, І. Фольварочного, О. Глузмана, Л. Пуховської, Т. Панського, В. Вдовенко, В. Семілетко, Г. Воронки, Т. Осадчої, Т. Кошманової та ін.).

Мета роботи - розглянути розвиток та здійснити огляд сучасної системи вищої освіти Греції на прикладі Університету ім. Аристотеля в м. Салоніках; визначити тенденції ї̈ розвитку.

Основна частина. Тенденції розвитку вищої освіти у деяких країнах донині виявляються i формуються по-різному. Історичні і політичні події, що мають місце в становленні і розвитку кожної держави, зумовлювали чималі зміни не лише, наприклад, в економіці країни, але і впливали на розвиток і функціонування системи вищої школи.

Щодо Грецької Республіки, то ця країна посідає особливе місце у світовому освітньому просторі і саме завдяки своєму специфічному економічному та політичному розвитку у галузі освіти представляє суттєвий інтерес для дослідників. За своїм географічним положенням Грецька Республіка розташована у Південно-Східній Європі. Загальна площа країни складає 131,9 км². Населення - 10,4 млн чоловік. Державна мова - грецька. Столиця - Афіни. Міське населення - 65\%. Глава держави - президент. Вищим законодавчим органом влади є однопалатний парламент. За економічними характеристиками Греція належить до середньорозвинених країн. Провідні галузі економіки - сільське господарство, легка і гірничовидобувна промисловість. Висока зайнятість населення у невиробничій сфері (50 \% ВНП). ВНП на душу населення складає 6000 \$ [2].

Окрім цього, Україну та Грецію поєднують давні культурні зв’язки, які беруть свій початок ще з доби античності, коли на території сучасної України були засновані грецькі колонії (Ольвія, Херсонес, Пантікапей тощо). Вищезазначені грецькі держави-поліси, залишаючись органічною частиною античної цивілізації, жили і розвивалися в тісній взаємодії з місцевим населенням й істотно впливали на його духовний та історичний розвиток. Це зумовило різноманітність культурних зв’язків після прийняття Київською Руссю християнства саме у його грекоримському варіанті. Можна навести ще багато прикладів тісної взаємодії України та Греції протягом усього історичного розвитку цих двох держав [3].

Одним із джерел становлення та розвитку вищої освіти в Греції є спогади російських мандрівників, які відвідали грецьку землю в кінці XIX - початку XX ст. Дослідники звертали увагу на різні фактори, які сприяли становленню і розвитку вищої грецької освіти. Вони відзначали демократичний характер системи навчання, прагнення студентів до отримання знань. У мемуарах міститься важлива інформація про відкриття університетів і атмосферу, яка в них панувала. Мандрівники вказували на європейський характер грецької освіти, повагу греків до власної культури та історії. Автори роблять висновок про те, що грецька вища освіта сприяла національній самосвідомості, створенню нової еліти грецького суспільства [6].

Вища освіта у Греції існує з перших років становлення нової Грецької держави (1821-1829). Коли на звільнених землях почали відроджуватися перші класи і школи та розпочалося становлення нової вільної держави, виникли передумови для розвитку нової системи освіти у Греції і її розподілу на три ступені: початкова школа ( $\delta \eta \mu о т к)$, середня

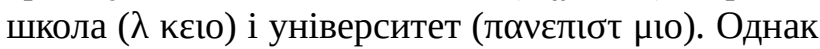
офіційно вища університетська освіта у Греції була визнана лише 22 березня 1833 р. У 1837 р. був заснований перший грецький університет, що знаходився у місті Афінах. 31862 р. він став Національним університетом м. Афін, у якому функціонували чотири факультети: теологічний, медичний, юридичний і філософський, де вивчалися також і природничі науки. У 1904 р. вивчення природничих наук здійснювалося не на факультеті філософії, а на створеному фізико-математичному факультеті.

Так, станом на 1904 р. у Національному університеті м. Афін нараховувалося вже 5 факультетів. У 1911 р. від Національного університету відокремилися теологічний, юридичний і філософський факультети як Університет ім. І. Каподістрії (університетові було присвоєно ім'я першого президента вільної Греції). Медичний і фізико-математичний факультети залишилися в Національному університеті. Головною причиною цього поділу стало виконання указу мецената I. Домболі, котрий активно допомагав становленню університету. Відповідно 
до указу, меценат залишав усе своє майно університетові за умови, що він буде перейменований в Університет ім. І. Каподістрії. У 1932 р. обидва університети об’єднали під назвою Національний

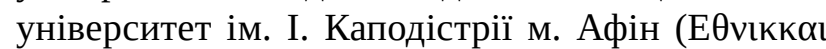

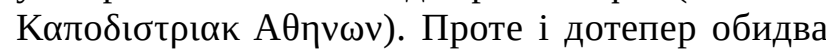
відділення мають різні статути, власні прапор і печатку. За роки правління країною президента К. Караманліса (з 1958 р.) зроблено значний внесок у розвиток вищої освіти Греції. За ці роки дві приватні промислові школи отримали статус вищого навчального закладу (Вища індустріальна школа Пірея і Вища індустріальна школа Салонік). Вища індустріальна школа Пірея спочатку була підпорядкована Міністерству національної економіки Греції, а з 1966 р. - Міністерству національної освіти і релігій Греції. Вища індустріальна школа Салонік почала працювати у 1948 р. як приватна школа, але з 1966 р. була підпорядкована Міністерству національної освіти і релігії Греції. Зазначимо, що перейменування двох індустріальних шкіл у вищі навчальні заклади не внесло значних поправок у так звану “карту вищої освіти Греції”. Як і колись, вищі навчальні заклади були розташовані у двох найбільших містах Греції - центрах культури, торгівлі, промисловості й освіти - в Афінах і Салоніках.

Сучасна система вищої освіти Греції децентралізована. Вища освіта містить два сектори: університетський та професійно-технічний. Конституція Греції надає університетам повну автономію та академічну свободу. Усі університети впроваджують і вдосконалюють післядипломне навчання студентів, вносять зміни у статути відповідно до європейських стандартів, прагнучи вийти на загальнодержавний рівень.

Сучасна “карта вищої освіти Греції” сьогодні нараховує 14 вищих навчальних закладів, 3 них 2 (Афінський і Салонікський університети) є університетами 3 найбільш розвиненим науково-дослідним потенціалом, 4 (університети Патр, Янніни, Фракії і Криту) з професійною спрямованістю освіти, 2 (Афінський політехнічний і Вища індустріальна школа Пірея) вищі навчальні заклади індустріального напряму і 6 незалежних університетів. У Греції існують також військові академії.

Управління освітою здійснює Міністерство освіти, науки та релігій. До основних його завдань належить оцінювати педагогічні потреби, визначати цілі і завдання освіти, розробляти законодавчі бази освітніх програм, координувати освітні потреби та послуги шкіл, надавати їм фінансову підтримку.
У вищій школі Греції прийнята загальноєвропейська двоетапна загальноосвітня система. Перший етап завершується отриманням диплома бакалавра. Його тривалість - від 4 років на факультетах гуманітарних і природничих наук, до 6 років у медицині. Другий етап - отримання ступеня магістра - можна пройти як у грецькому вузі, так і в будь-якому навчальному закладі іншої країни за відповідною програмою. Проте існує і третій ступінь вищої освіти докторантура. Ступінь доктора наук присвоюється після публічного захисту докторської дисертації. Дослідження, здійснене здобувачем, має бути оригінальним і демонструвати прогрес у дослідженні обраної галузі. Тривалість навчання за програмою докторського циклу складає як мінімум три роки. Згідно з чинною Конституцією Греції (ст. 16.8), засновувати недержавні вищі освітні заклади в країні заборонено. Державну вищу освіту можна здобути тільки в університетах та інститутах технічної освіти. Вступити до них можна за результатами іспитів після другого або третього класу ліцею. Салоніки - друге за розміром місто Греції, столиця регіону Македонія, місто з історією, що нараховує більше 2-х з половиною тисяч років, місто, в якому змішалися культури античних греків, римлян, візантійців, турків та сучасних європейців. Саме в ньому розташований найбільший університет як у Греції, так і на Балканському півострові - Університет ім. Аристотеля.

Університет ім. Аристотеля у м. Салоніках, який був заснований в 1925 р., на сьогодні є найбільшим університетом не тільки в Греції, але і на Балканах. На даний час у ньому працює загалом 7 інститутів, що охоплюють широкий спектр наукових напрямів. Більше 100000 студентів, викладачів і співробітників трудяться на благо розвитку науки в різних категоріях. Величезна кількість молодих учених задіяна в науково-дослідних програмах національного та світового масштабу [5].

В університеті проходить яскраве і насичене культурне та спортивне життя. Бібліотека Університету ім. Аристотеля є однією з найбільших бібліотек на Балканському півострові і є другою за величиною грецькою бібліотекою, відразу ж після Національної бібліотеки. Кафедра фізичної культури та спорту пропонує багато можливостей для реалізації спортивних здібностей студентів.

Університет ім. Аристотеля підписав 592 активні двосторонні угоди з обміну студентами і викладачами. Має договір про наукове співробітництво більш ніж з 100 університетами і вищими навчальними 
закладами Європи, Балкан, Росії, США, Канади, Австралії, Африки, Латинської Америки, Близького, Середнього і Далекого Сходу.

Університет бере участь у 48 науково-дослідних мережах, реалізує щороку більше 1400 національних, європейських і міжнародних дослідницьких проектів і тісно співпрацює з багатьма університетами, дослідницькими інститутами та компаніями як у Греції, так і за кордоном.

Університет ім. Аристотеля розташований у самому центрі міста Салонік і займає три величезні квартали (площа близько 33 га). На даний час у ньому навчається близько 75000 студентів на 11 факультетах (теології, філософії, природничих наук, економіки, юридичний, медичний, інженерний, образотворчих мистецтв, педагогічний, сільськогосподарський та факультет спортивних наук). Зі свого боку, кожний факультет має у своєму складі декілька шкіл з різними напрямками навчання, загальною кількістю - 40. Наприклад, медичний факультет складається зі шкіл: медицини, ветеринарної медицини, фармації та стоматології. На території університету знаходиться власна університетська лікарня [5].

Університетська лікарня міста Салонік “АХЕПА”

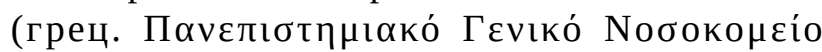

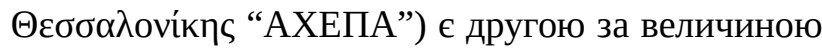
лікарнею в Салоніках після Лікарні ім. Гіппократа і однією з найбільших у Греції. Вона співпрацює з Університетом ім. Аристотеля в Салоніках і розташована в студентському містечку в центрі міста. Клініка була створена в 1947 р. за фінансової підтримки АХЕПА (грец. АХЕПА; англ. АНЕРА), греко-американської благодійної організації. Доти медичний факультет університету працював у старих лікарнях, колишніх тютюнових магазинах та інших, не пристосованих для цього, будівлях. Лікарню офіційно відкрили в 1951 р., під час святкування 25-ї річниці Університету ім. Аристотеля в Салоніках. Хоча насправді лікарня розпочала своє функціонування у березні 1953 р. Спочатку вона складалася з одного двоповерхового корпусу і мала всього 120 місць у трьох відділеннях: хірургії, внутрішньої медицини та амбулаторії, а також чотири лабораторії (рентгенології, мікробіологічну, біохімічну і патологоанатомічну). 3 часом збільшилися потреби не тільки медичної школи, але і Салонік, і загалом Македонії. Це наклало свій відбиток на подальшому розширенні лікарні. Так, Університет ім. Аристотеля в 1987 р. віддав на потреби лікарні три, тоді ще недобудованих, будівлі. Спочатку вони призначалися для психоневрологічного інституту. У кінці 1987 р. будівельні роботи були завершені. В одному з них розташувалися клініки неврології та нейрохірургії, відділення інтенсивної терапії нейрохірургічних хворих та інші допоміжні підрозділи, а в двох інших - клініка патологічної хірургії, психіатрична клініка, відділення ядерної медицини та ін. У 1990 р. завершено будівництво та обладнаний ще один корпус, в якому розмістилося амбулаторно-поліклінічне відділення. 3 грудня 2002 р. за лікарнею АХЕПА законодавчо закріплений статус Академічного медичного центру, що налічує 720 ліжко-місць і обладнаний найсучаснішим лікувально-діагностичним обладнанням, який надає найширший спектр медичної допомоги, необхідної жителям Салонік і Північної Греції відповідно до їх потреб [5].

Вища освіта, отримана в Греції, цінується у світі дуже високо. Навчання в державних університетах тільки безкоштовне. Щоб вступити до них, греки складають по 12 іспитів. Зарубіжні абітурієнти вступають на основі середнього бала атестата без складання вступних іспитів. Упродовж першого року такі студенти проходять посилені курси 3 грецької мови, вивчають історію та літературу. Навчання за фахом починається тільки з другого курсу і після складання іспиту з грецької.

Для прикладу, медична освіта в Греції має три ступені. Щоб отримати перший медичний диплом, який відповідає рівню бакалавра, вчаться шість років. Після цього можна піти в резидентуру і зайнятися практичною діяльністю, а можна продовжити навчання і ще через 3 роки отримати диплом магістра. Третій ступінь представлений докторантурою. Вступати до неї можна після отримання ступеня магістра і мінімум трьох років роботи з лікарської спеціальності. Докторантура дозволяє вести наукову діяльність.

Висновки. Підсумовуючи вищезазначене, можна стверджувати, що Грецька держава завжди сприяла розвитку системи вищої освіти, яка багато в чому стала сполучною ланкою між державною ідеологією і широкими верствами грецького населення. У процесі навчання в університетах Греції створювалася нова політична еліта, відповідальна за майбутнє своєї країни. Також слід зазначити, що система вищої освіти Греції має потребу в заснуванні принципово нових університетів, причому нових не за датою створення, а за організацією роботи, засобами навчання, нарешті - за новими спеціальностями. Усі вищі навчальні заклади Греції створені за 
принципом найстарішого Афінського університету, а тому і вся університетська система країни формується навколо трьох класичних факультетів: філософського, юридичного і фізико-математичного.

Вступ Греції до Євросоюзу та приєднання до Болонського процесу, необхідність подолання сучасної економічної кризи, підвищення темпів зростання економіки, багата культура, тісні зв'язки 3 іншими країнами - все це зумовлює необхідність відкриття нових факультетів і започаткування нових спеціальностей, реформування системи вищої освіти в країні, подальшого зростання з “класичного” рівня на більш високий і сучасний.

\section{Список літератури}

1. Глузман О. В. Університетська педагогічна освіта: досвід системного дослідження / О. В. Глузман. - К. : Просвіта, 1997. - 312 с.

2. Енциклопедія освіти / Акад. пед. наук України ; гол. ред. В. Г. Кремень. - К. : Юрінком Інтер, 2008. - 1040 с.

3. Короткова Ю. М. Професійна підготовка вчителя початкових класів у сучасній Греції : дис. на здобуття наук. ступеня кандидата пед. наук : 13.00.01 / Ю. М. Короткова. - Х., 2008.

4. Пуховська Л. П. Професійна підготовка вчителів у Західній Європі в кінці ХХ століття : дис. на здобуття наук. ступеня доктора пед. наук : 13.00 .04 / Л. П. Пуховська. - К., 1998. - 441 с.

\section{References}

1. Gluzman, O.V. (1997). Universytetska pedahohichna osvita: Dosvid systemnoho doslidzhennia [University pedagogical education: the experience of system research]. Kyiv: Prosvita [in Ukrainian].

2. Kremen, V.H. (Ed.). (2008). Entsyklopediia osvity [Encyclopedia of education]. Kyiv: Yurinkom Inter [in Ukrainian].

3. Korotkova, Yu.M. (2008). Profesiina pidhotovka vchytelia pochatkovykh klasiv u suchasnii Hretsii [Professional training of elementary school teachers in modern Greece]. Candidate's thesis. Kharkiv [in Ukrainian].

4. Pukhovska, L.P. (1998). Profesiina pidhotovka vchyteliv u Zakhidnii Yevropi v kintsi XX stolittia [Teacher training in Western Europe at the end of the twentieth century]. Doctor's thesis. Kyiv [in Ukrainian].

5. Osvita likariv za kordonom - v SShA, Kanadi, Nimechchyni, Shvetsii, Italii, Izraili, Hretsii, Avstrii, Chekhii,
Провідна роль університету була історично обумовлена в системі освіти України і Греції. Перетворюючись в університетські комплекси і науково-дослідні центри, університети функціонуватимуть як інститути, що вирішують проблеми наукових досліджень, обслуговування суспільства, підготовки фахівців високого класу, формування інтелектуальної еліти країни.

До подальших досліджень можна віднести порівняльний аналіз особливостей підготовки майбутніх медиків України та Греції з метою вивчення та можливого застосування позитивного досвіду грецьких науковців вітчизняними вищими медичним закладами освіти.

5. Освіта за кордоном - в США, Канаді, Німеччині, Швеції, Італії, Ізраїлі, Греції, Австрії, Чехії, Польщі [Електронний ресурс]. - Режим доступу до документа : http://ukrpromedic.ru/rizne/medichni-novini-tastatti/22282-osvita-likariv-za-kordonom-v-ssha-kanadi. html.

6. Булычева Е. В. Университетское образование в Греции конца XIX - начала XX в. глазами русских путешественников [Электронный ресурс] / Е. В. Булычева // Вестник РГГУ. Серия “История. Филология. Культорология. Востоковедение”. - 2012. - № 9 (89). - Режим доступа к документу: https:/cyberleninka.ru/article/n/ universitetskoe-obrazovanie-v-gretsii-kontsa-xix-nachalahh-v-glazami-russkih-puteshestvennikov-1.

Polshchi [Education of doctors abroad - in USA, Canada, Germany, Sweden, Italy, Israel, Greece, Austria, Czech Republic, Poland]. Medychni novyny ta statti - Medical News and Articles. Retrieved from: http://ukrpromedic. ru/rizne/medichni-novini-ta-statti/22282-osvita-likariv-zakordonom-v-ssha-kanadi.html [in Ukrainian].

6. Bulicheva, E.V. (2012). Unyversitetskoe obrazovaniye v Gretsii kontsa XIX - nachala XX v. glazamy russkikh puteshestvennikov [University education in Greece late XIX-early XX century. through the eyes of Russian travelers]. Vestnik RGGU. Seriya "Istoriya. Filologiya. Kultorologiya. Vostokovedeniye" - Herald of the RSUH. Series "History. Philology. Cultorology. Oriental Studies", 9 (89). Retrieved from: https://cyberleninka.ru/article/n/ universitetskoe-obrazovanie-v-gretsii-kontsa-xix-nachalahh-v-glazami-russkih-puteshestvennikov-1 [in Russian]. 